\title{
Tudományos felfedezéses tanulás a fogalmi tárgykörök számítógépes szimulációjával
}

A tudományos felfedezéses tanulás a tanulás nagy mértékben önirányítással megvalósuló, konstruktív formája. A számítógépes szimuláció olyan számítógép -alapú környezet, amely kiválóan alkalmas a felfedezéses tanulásra, mivel itt az a tanuló fő feladata, hogy kísérletezés útján következtessen a szimuláció alapját képező modell tulajdonságaira. A neves holland szerzők tanulmánya áttekintést ad a szimulációs környezetekben megvalósuló felfedezéses tanulás megfigyelt hatékonyságáról és hatásosságáról, rámutatva azokra a problémákra, amelyekkel a tanulók ilyenkor találkozhatnak, továbbá arról, hogy ezeknek a problémáknak a megoldása érdekében a szimuláció hogyan kombinálható tanári segítséggel.

\section{Szerzői információ:}

Ton de Jong

Jelenleg a Twente-i Egyetem Viselkedéstudományi Karán oktatástechnológiát és oktatáspszichológiát tanít. Érdeklődésének középpontjában a problémamegoldás áll, amit a tudományokkal, a számítógépes szimulációt alkalmazó tanulási környezetekkel, a tanulókban lejátszódó kognitív folyamatokkal és az ember-gép rendszerek határterületeivel kapcsolatban vizsgál.

Az EC-Telematics SERVIVE projektjének vezetőjeként egy olyan kiadványszerkesztôi segédprogram (SIMQUEST) tervezését irányította, amely integrált szimulációs tanulási környezetek létrehozására képes. Ezzel a programmal 2000-ben elnyerte a legjobb európai tudományos szoftver készítôjének évente odaítélt díjat (EASA: European Academic Software Award).

Jelenleg az alábbi kutatási programokat vezeti: „A tudásmenedzsment elsajátítása játszva” (KITS projekt), „Tanulás a tudományok virtuális laboratóriumaiban” (Co-Lab projekt), „A pszichológia interaktív vizuális megjelenési formái” (SURF ZAP projekt).

Wouter R. Van Joolingen

1987-ben szerzett diplomát elméleti fizikából a Leideni Egyetemen. Ezután közel másfél évig számítógépes szimulációs programokat írt a fizikaoktatáshoz, majd az Eindhoveni Muszaki Egyetem Oktatási Kutatócsoportjának tagja lett. 1993-ban doktorált, kutatási témája: „A felfedezéses tanulás elôsegítése számítógépes szimulációs programokkal".

1995-tốl több európai projektben, többek között a SERVIVE programban is dolgozott. Tanulmányai és kutatói munkája során érdeklődésének középpontjába a fizikaoktatás helyett egyre inkább az oktatás, a neveléstudomány került. Jelenleg az Amszterdami Egyetem docenseként elsosorban azzal foglalkozik, hogy a felfedezéses tanulás során a tanulók együttmúködő viselkedésének szempontjából hogyan alakíthatók optimálisan a környezeti tényezók.

Így hivatkozzon erre a cikkre:

de Jong, Ton, Wouter R. Van Joolingen. „Tudományos felfedezéses tanulás a fogalmi tárgykörök számítógépes szimulációjával”. Információs Társadalom III, 2. szám (2003): 8-33.

ב https://dx.doi.org/10.22503/inftars.III.2003.2.1 $\bar{~}$

A folyóiratban közölt müvek

a Creative Commons Nevezd meg! - Ne add el! - Így add tovább! 4.0

Nemzetközi Licenc feltételeinek megfelelően használhatók. 
Ton de Jong, Wouter R. Van Joolingen

\section{Tudományos felfedezéses tanulás a fogalmi tárgykörök számítógépes szimulációjával}

Az oktatás és a tanulás világára ma jelentôs befolyást gyakorol az úgynevezett „konstruktív pedagógia” hatása. Ez az irányzat erôsen hangsúlyozza a tanuló aktív cselekvő személyét a tudásszerzési folyamatban. Az objektivista hagyományok jegyében a tanulók előrehaladását számítógép-alapú tanulási környezetben követték nyomon, fejlődésüket programozott tanulás, tutori foglalkozások és gyakorló programok segítségével előmozdítva (Alessi-Trollip 1985) - hasonlóképpen a konstruktív pedagógia gyakorlatában is jelentôsen hozzájárul a tanulók fejlődéséhez a számítógépes tanulási környezet. Ilyen lehet például a hipertext környezet (lásd pl. Gall-Hannafin 1994), a fogalmi gondolkodás szerkezetét feltérképező környezet (pl. Novak-Wandersee 1990), a šimuláció (De Jong 1991; Reigeluth-Schwarz 1989) és a modellező környezet (pl. di Sessa-Abelson 1986; Riley 1990; Smith 1986).

Ebben a tanulmányban figyelmünket a számitógépes szimuláció tanulási alkalmazására összpontosítjuk, mivel a szimuláció segítségével történő tanulás közel áll a konstruktív tanulás egyik speciális formájához, nevezetesen a tudományos felfedezéses tanuláshoz. Először rövid értelmezést adunk e két kulcskifejezéshez (számítógépes szimuláció, illetve tudományos felfedezéses tanulás), majd röviden áttekintjük azokat a kutatásokat, melyek során a tanári segítség nélküli, szimulációra alapozott felfedezéses tanulást a kifejtéses oktatás valamilyen formájával hasonlították össze. Ezek a kutatások rámutatnak arra, hogy a szimuláció alapú tanulás előnyei nem mindig valósulnak meg. Ennek az egyik oka az, hogy a felfedezéses tanulás közben a tanulóknak különféle problémáik adódnak, s innen egyenes út vezet tanulmányunk fő kérdéseihez: melyek a tanulók problémái a felfedezéses tanulás során? Hogyan tervezhetünk olyan szimulációs környezeteket, amelyek segítik a tanulókat a problémák megoldásában?

A számítógépes szimuláció olyan program, amely egy (természetes vagy mesterséges) rendszer vagy eljárás modelljét állítja elô. A számítógépes szimulációk nagyjából két típusra oszthatók: konceptuális modellt tartalmazó szimulációk és operációs modellre épülő szimulációk. A konceptuális modellek elveket, koncepciókat és tényeket reprezentálnak, amelyek a szimulált rendszerekre és ezek alfajaira vonatkoznak. Az operációs modellek kognitív és nem-kognitív múveletek (vagy eljárások) sorozatait tartalmazzák, amelyek alkalmazhatók a szimulált rendszerekre (vagy azok valamely osztályára). A konceptuális modellekre jó példák találhatók a közgazdaságtanban (Shute-Glaser 1990) és a fizikában (pl. elektromos áramkörök, White-Frederiksen 1989; 1990). Operációs modellekkel találkozhatunk pédául a radar-irányítással kapcsolatos feladatoknál (Munro, Fehling és Towne 1985). Az operációs modellek általában az empirikus tanulásnál használatosak, a felfedezéses tanulásnál fốleg konceptu- 
ális szimulációkat találunk. A konceptuális modellek széles skáláján sokféle típus ismeretes: minőségi és mennyiségi, folyamatos és diszkrét, valamint statikus és dinamikus modellek (ld. Van Joolingen-De Jong 1991a). A modellek komplexitása is jelentősen eltérhet egymástól, találhatunk köztük nagyon egyszerû és egyértelmú modelleket (pl. egyszerű mendeli genetika: Brant, Hooper és Sugrue 1991), valamint rendkívül komplex modelleket is (ilyen pl. az orvostudományi tárgyú HUMAN szimulációs program, amelyben 200 változó és paraméter kombinálható: Coleman-Randall 1986). A konceptuális modellt olyan specifikus tulajdonságok jellemzik, mint a változók helye a modellben, illetve az elméleti és operációs változók közti távolság (Glaser, Schauble, Raghavan és Zeitz 1992). A tudományos felfedezéses tanulás során az a tanulók fó feladata, hogy a szimuláció alapján következtessenek a modell tulajdonságaira. Ehhez módosítaniuk kell az input változók értékeit és meg kell figyelniük az output értékeiben ebból adódó változásokat (De Jong 1991; Reigeluth-Schwarz 1989). A szimulációs környezetben az input betáplálásának és az output megjelenítésének az eszközei eleinte felettébb korlátozottak voltak, de ma már kezdenek elterjedni az input direkt manipulációját, valamint az output grafikus és animációs megjelenítését lehetôvé tevő, egyre kifinomultabb interfészek (pl. Härtel 1994; Teodoro 1992; Kozma, Russel, Jones, Marx és Davis 1996) és - legújabb fejleményként - a virtuális valóság-környezetek (lásd pl. Thurman-Mattoon 1994).

A felfedezéses tanulás koncepciója a Gestalt pszichológiában és Bruner munkáiban (1961) gyökerezik. A felfedezéses tanulási módszerek kutatása az elmúlt néhány évtized során eltávolodott a fogalmak felfedezésétôl (amire Bruner tanulmányai irányultak) és egy új irányban fejlődött tovább, amit „tudományos felfedezéses tanulásnak” neveztek el (Klahr-Dunbar 1988; Reimann 1991). A tudományos felfedezéses tanulás elméletei rendszerint a tudományos felfedezés elméletein alapulnak. Rivers és Vockell (Rivers-Vockell 1987) például olyan ciklusként írják le ezt a folyamatot, amely tervből (a kísérlet megtervezéséből), végrehajtásból (a kísérlet elvégzéséből és adatok gyüjtéséből) és értékelésböl (az adatok elemzéséből és hipotézis kidolgozásából) áll. Friedler, Nachmias és Linn (Friedler, Nachmias Is Linn 1990:173) szerint a tudományos okfejtés a következő lépéseket, illetve az ezekhez szükséges képességeket kívánja meg:
„(a) a tudományos probléma meghatározása;
(b) hipotézis felállítása;
(c) kísérlet megtervezése;
(d) megfigyelés, adatok gyûjtése, elemzése és értelmezése;
(e) az eredmények alkalmazása;
(f) előrejelzések megfogalmazása az eredmények alapján”.

De Jong és Njoo (De Jong-Njoo 1992) különbséget tesznek a tudást közvetlenül nyújtó, Friedler és társai (Fridler et al. 1990), valamint Rivers és Vockell (Rivers-Vockell 1987) által vizsgált transঞformatív eljárások és az olyan regulatív eljárások között, mint például a tervezés és a monitoring, amelyek szükségesek a felfedezési folyamat irányításához. A tudományos felfedezéses tanulásról alkotott elméletek második csoportja Simon munkásságából merít (vö. Kulkarni-Simon 1988; Qin-Simon 1990; Simon-Lea 1974). Ezen a területen az egyik legjelentősebb tudományos ered- 
mény Klahr és Dunbar (Klahr-Dunbar 1988) SDDS elmélete (Scientific Discovery as Dual Search: „Tudományos felfedezés mint kettős kutatás), aminek a központi fogalmait kétféle tér alkotja: a hipotézis-tér és a kisérleti tér. Az SDDS elméletben a hipotézis-tér olyan keresési tér, ami magában foglalja az összes szabályt, amelyekkel leírhatók az adott területen megfigyelhetô jelenségek. A kísérleti tér azokból a kísérletekből áll, amelyek véghezvihetôk a vizsgált területen belül, s ide tartoznak ezeknek a kísérleteknek az eredményei is. Noha az $S D D S$ elméletben a keresési terek struktúráján van az elsődleges hangsúly, Klahr és Dunbar jelentős figyelmet fordított a felfedezési folyamatokra is.

A számítógéppel segített oktatás egy korai áttekintésében Bangert-Drowns, Kulik és Kulik (Bangert-Drowns, Kulik és Kulik 1985) arról számoltak be, hogy a szimulációra alapozott tanulás nem javítja a vizsgaeredményeket. A konceptuális modelleket tartalmazó „tiszta” szimulációk alapján végbemenő tanulást számos későbbi vizsgálatban (néha több változó összehasonlítására is kiterjedố kutatások részeként) öszszevetették a kifejtéses oktatás valamilyen formájában számítógépes egyéni foglalkozásokon és osztálytermi tanórák keretében) történô tanulással. Ezeket a kutatásokat az alábbi tudományterületeken végezték: biológia (Rivers-Vockell 1987), közgazdaságtan (Grimes-Willey 1990), newtoni mechanika (Rieber, Boyce és Assad 1990; Rieber-Parmley 1995), elektromos áramkörök (Carlsen-Andre 1992; Chambers et al. 1994). Néha pusztán a szimulációt is egybevetik a kifejtéses oktatással (Rieber-Parmley 1995), de a tantervbe vagy a kifejtéses oktatásba beágyazott szimulációnak és a tantervnek vagy a kifejtéses oktatásnak mint olyannak az összehasonlítására jóval gyakrabban kerül sor (Carlsen-Andre 1987; Chambers et al. 1994; Grimes-Willey 1990; Rieber et al. 1990; Rivers-Vockell 1987). Néhány esetben elôfordul az is, hogy a kifejtéses oktatást, amivel a szimulációt összehasonlítják, például fogalmi változásokra utaló különféle elemekkel „gazdagítják” (Chambers et al. 1994; Rieber et al. 1990). Ami az átfogó képet illeti, Grimes és Willey (Grimes-Willey 1990) tanulmányukban a szimuláció-alapú tanulás kedvező eredményeiről számolnak be. Carlsen és Andre (Carlsen-Andre 1992), valamint Chambers és társai (Chambers et al. 1994) szerint viszont a szimuláció alapú tanulás és a tanári magyarázaton alapuló oktatás között semmilyen különbség nincs. Kedvező és pozitív változás nélküli eredmények egyaránt találhatók Rivers és Vockell (Rivers-Vockell 1987) számos tanulmányában. Rieber és társai (Rieber et al. 1990) szerint a tanulóknak az a csoportja, amelyik a tanórák mellett kiegészítésképpen részt vett szimulációban is, a szabályok alkalmazását mérố teszten magasabb pontszámot ért el, mint a csak osztálytermi foglalkozásokon résztvevő csoport, de ugyanúgy szerepelt, mint az a hagyományos módszerrel, tanárok által oktatott csoport, ahol tanulás közben kiegészítő kérdéseket tettek fel. Rieber és Parmley (Rieber-Parmley 1995) szerint azok a diákok, akik csak strukturálatlan (tiszta) szimulációk segítségével tanultak, rosszabb teljesítményt mutattak, mint azok, akik egyszerú tanórákon vettek részt.

A fenti tanulmányok alapján megállapítható, hogy nincs olyan világos és egybehangzó eredmény, ami a szimulációk mellett szólna. Annak, hogy a szimulációra alapozott tanulás miért nem fejleszti a tanulási eredményeket, egy lehetséges magyarázatát a módszer lényegébôl fakadó belsô problémák adják, amelyekkel a tanuló szemben találhatja magát a felfedezéses tanulás során. A fent említett tanulmányok - köztük pl. Chambers és társai (Chambers et al. 1984) elemzése a szimulációval dolgozó 
tanulókról készült videokazettákról - azt jelzik, hogy a váratlan eredményekkel a tanulók nem tudtak mit kezdeni, és nem hasznosítottak minden kísérletezési lehetőséget, ami rendelkezésükre állt. Azok a vizsgálatok, amelyek összehasonlították a sikeres és sikertelen tanulók tanulási magatartását a szimulációs tanulási környezetekben (pl. Schauble, Glaser, Raghavan és Reiner 1991), szintén rámutattak a tanulók tudásának bizonyos hiányosságaira. Ezért a tanulmányok egy része olyan további oktatási lépéseket javasol, amelyek segíthetik a tanulókat a tudományos felfedezés útján történő tanulás során felmerülố problémák megoldásában.

A következôkben áttekintést adunk a szimulációval segített felfedezéses tanulás problémáiról, útmutatást keresünk ahhoz, hogyan lehet megküzdeni ezekkel a problémákkal és megvizsgáljuk a szimulációk különféle kiegészítő oktatási lépésekkel való kombinációjának a hatásával kapcsolatos kutatási eredményeket. Az a szakirodalom, ami keretet nyújt ezeknek a kérdéseknek a tárgyalásához, több forrásból származik. Először a Kognitív Kutatási és Fejlesztési Laboratórium (Laboratory for Research and Development in Cognition), illetve a Carnegie Mellon Egyetem jelentős kutatási programjaival (lásd pl. Klahr-Dunbar 1988; Reimann 1991; Schauble et al. 1991; Shutes-Glaser 1990) foglalkoztunk. Ezeknek a dokumentumai nemcsak a jelen beszámoló összeállításánál voltak hasznosak, hanem értékes forrást nyújtottak a számítógépes szimuláció segítségével folyó tudományos felfedezéses tanulással kapcsolatban másutt végzett vizsgálatok megismeréséhez is. Azután on-line kutatást folytattunk különféle keresőprogramokkal. A Pedagógiai Információs és Forrásközpont (Educational Resources Information Center - ERIC) adatbázisában a „számítógépes szimuláció(k)" kulcsszó használatával 1997 júniusában 2073 tanulmányt találtunk. Mivel az elóbbi kulcsszavak és a „felfedezéses tanulás”, illetve a „felfedezési folyamatok" kifejezések kombinálásával a tanulmányok olyan listáját kaptuk, amelyben néhány általunk ismert jelentốs közlemény nem szerepelt, az ERIC rendszerben átvizsgáltuk mind a 2073 tanulmány kivonatát. Áttekintettük továbbá azokat a konferencia-előadásokat, amelyek többek között az Amerikai Pedagógiai Kutatási Társaság (American Educational Research Association) és az Európai Oktatás- és Tanulás-Kutatási Egyesület (European Association for Research on Learning and Instruction) által szervezett országos és nemzetközi konferenciákon, valamint „à mesterséges intelligencia oktatási alkalmazásának" témájában rendezett világkonferencián (World Conference on Artificial Intelligence in Education) és az „intelligens oktató rendszerekkel” foglalkozó nemzetközi konferencián (International Conference on Intelligent Tutoring Systems) hangzottak el, és megvizsgáltuk az utóbbi öt év folyamán szerkesztett gyưjjteményes kötetek tartalmát is. Ezen kívül fizikailag átvizsgáltunk több kiválasztott tudományos folyóiratot, amelyekről valószínűnek láttuk, hogy közölnek számítógépes szimulációval foglalkozó tanulmányokat. Ezek közül itt megemlítjük a Journal of Research in Science Teaching, a Computers \& Education, a Journal of Computer-Based Instruction, az Instructional Science és a Journal of the Learning Sciences című folyóiratokat. A mi témánk - a számítógépes szimulációval segített felfedezéses tanulás - szempontjából fontos tanulmányok négy típusát különböztettük meg. Elôször is, találtunk olyan tanulmányokat, amelyek csupán a tanulási környezetet írják le - ezeket „mérnöki” tanulmányoknak nevezhetnénk. A második típushoz azok az elméleti jellegú tanulmányok tartoznak, amelyek a felfedezéses tanulás és a szimuláció elméleti kér- 
déseivel foglalkoznak. Harmadszor, találtunk olyan tanulmányokat, amelyek empirikus adatokat gyújtöttek össze - például automatikusan generált feljegyzéseknek ( $\log$ fájloknak) vagy a „hangosan gondolkodás” módszerének a felhasználásával - a felfedezéses tanulás folyamatáról. A negyedik típushoz azokat a kísérleti úton folytatott vizsgálatokról beszámoló tanulmányokat soroltuk, amelyek a szimulációs környezeteket a kifejtéses oktatással összevetve értékelik, vagy amelyek lényegében ugyanazon szimulációs környezet különböző változatait hasonlítják össze. A válogatás során a következôképpen jártunk el: először is kizártuk a kísérleti beszámolókat, ha nem gondosan ellenőrzött kísérleti körülményeket vagy pontosan meghatározott teljesítmény-mérési módszereket találtunk bennük, másodszor pedig a jelen beszámoló céljaira kiválasztottuk az eredeti kutatási közleményeket és kizártuk az ezeket követốen megjelent írásokat, amelyek csupán más formában ismertették ezek eredményeit vagy ugyanazt a gondolatmenetet ismételték meg.

\section{A felfedezéses tanulás során felmerïlő problémák}

A következőkben azonosítunk egy sor tipikus problémát, amelyekkel a tanulók a felfedezéses tanulás során találkozhatnak, s ezeket a felfedezéses tanulás főbb lépései - a hipotézisek felállítása, a kísérletek megtervezése, illetve lebonyolítása és az adatok elemzése - szerint csoportosítva tárgyaljuk. A tanulás szabályozásával kapcsolatos kérdésekkel külön foglalkozunk.

\section{Hipotézis-alkotás}

Az új hipotézisek kidolgozása közismerten nehéz feladat (Chinn-Brewer 1993), amelynek a megoldása alapján a sikeres és a sikertelen tanulók világosan megkülönböztethetők (Schauble, Glaser et al. 1991). Itt fontos problémát jelent, hogy a tanulók (ideértve az egyetemi hallgatókat is) egyszerủen nem tudhatják, hogy egy hipotézisnek milyennek kell lennie. Njoo és De Jong (Njoo-De Jong 1993a) a tanulási lépések „szabatosságát” vizsgálták 91 gépészmérnök hallgató esetében, akik egy szabályozáselméleti téma szimulációján dolgoztak. Megfigyelték a szintaktikai korrektséget, amivel a tanulók kitöltötték a munkához rendelkezésükre bocsátott űrlapokat. A hipotézis kidolgozásának folyamatában például nemcsak azt vizsgálták, hogy a tanulók hipotézisei az adott tudományterületen korrektek voltak-e, hanem azt is, hogy a hipotéziseket változók és a köztük levố kapcsolatok meghatározásával állították-e fel. A feljegyzett tanulási lépések korrektségét tekintve átlagosan 42\%-os, a hipotézis-alkotás „szabatosságára” nézve pedig még alacsonyabb eredményeket kaptak.

Egy másik probléma az, hogy az összegyújtött adatok alapján a tanulók esetleg nem képesek felállítani vagy módosítani hipotéziseiket. Klahr és Dunbar (Klahr-Dunbar 1988) úgy találták, hogy a tanulóknak a nem visszaigazoló kísérletekből a megfigyelt esetek 56\%-ában nem sikerült a helyes következtetést levonni: negatív kísérleti eredmények alapján helytelenül állították fel hipotéziseiket. Más tanulmányok szintén hangsúlyozzák a tanulók ellenállását az általuk felállított elméletek megváltoztatásával szemben. Chinn és Brewer (Chinn-Brewer 1993) hét olyan tipikus tanulói reakciót írnak le, amelyeket „rendellenes” adatok váltanak ki a tanulók- 
ból, s ezek közül csak az egyik az elmélet módosítása az adatok alapján. Számos tanulmányra hivatkoznak, amelyekben az olvasható, hogy a rendellenes adatokat a tanulók elvetették, függóben tartották vagy átértelmezték, egyszóval figyelmen kívül hagyták (ld. még Chambers et al. 1994), és megtartották a korábbi elméletet, vagy csupán marginális változtatásokat végeztek az elméleten (Chinn-Brewer 1993:4). Dunbar (Dunbar 1993) szintén talált bizonyítékot arra, hogy a tanulóknak általában nehézséget okoz az eredetileg kitûzött célok elejtése, ami ahhoz vezet, hogy kitartóan ragaszkodnak egy-egy hipotézishez, ahelyett, hogy újat állítanának fel. Magyarázatképpen Dunbar (Dunbar 1993) az „alternatív hipotézis kigondolására való képtelenség" jelenségét említi, azt értve ez alatt, hogy a tanulók ellentmondó bizonyítékok ellenére is ragaszkodnak a hipotézisükhöz, egyszerûen azért, mert nincs alternatívájuk. Ezek az eredmények ahhoz az általános feltételezéshez vezethetnek, hogy az emberekben erôs hajlam él eredeti elgondolásaik fenntartására. Klahr és Dunbar (Klahr-Dunbar 1988) mindazonáltal találtak egy ezzel ellentétes jelenséget is: a tanulók elvetnek hipotéziseket nem visszaigazoló kísérleti eredmények nélkül is. Az adatok elméletté alakításának ezt az általános problémáját Kuhn, Schaubleés GarciaMila (Kuhn, Schauble és Garcia-Mila 1992) tanulmánya illusztrálja. Az általuk vizsgált tízéves tanulók egyetlen kísérleti foglalkozás folyamán sokszor (10-11 alkalommal) változtatták meg a tárgykörben megfigyelt valamilyen változás oksági összefüggéseire vonatkozó elképzeléseiket. Az elgondolások gyakori változása részben azzal a ténnyel magyarázható, hogy a szóbanforgó vizsgálat során a tanulók sok esetben alakítottak ki olyan - igen változatos - elképzeléseket, amiket Kuhn és társai „érvénytelen következtetésnek" neveztek. Egyetlen eset alapján is vontak le következtetéseket ok-okozati összefüggésról, vagy következtetésekre jutottak egy-egy olyan változóról, amelynek az értékét két kísérlet során nem változtatták meg. A hipotézis kísérleti adatok alapján való módosításának képességét bizonyára befolyásolja a távolság az elméleti változók és a szimulációban manipulált változók között (Van Joolingen-De Jong 1997). Glaser és tsai (Galser et al. 1992) azt állítják, hogy az egyenáramú hálózatokat szimuláló Voltaville és a fénytörést szimuláló Refract környezetekben a tanulóknak könnyebb meglátni a kapcsolatot a lencsék, távolságok, ellenállások stb. manipulációi és az elméleti modell között, mint egy olyan környezetben, mint például a közgazdaságtani tárgyú Smithtown, ahol az elméleti változók és a szimulációban manipulálható változók közt nagyobb a távolság.

A hipotézis-alkotás harmadik problémája az, hogy a tanulókat olyan megfontolások is vezethetik, amelyek nem feltétlenül segítenek megtalálni a helyes (vagy a legjobb) elméleti megközelítést. Van Joolingen és De Jong (Van Joolingen-De Jong 1993) leírnak egy jelenséget, amit az elvetéstól való félelemnek neveznek. Az általuk bevezetett úgynevezett „hipotézis-jegyzetblokk” használatának elemzésekor 31 tanuló munkáját vizsgálva úgy találták, hogy azok hajlamosak elkerülni az olyan hipotéziseket, amelyeknél nagy az esély arra, hogy el kell vetni óket, például olyan esetekben, amikor nagy precizitással kell meghatározni a változók összefüggéseit. Hasonló jelenséget ír le Klayman és Ha (Klayman-Ha 1987), valamint Klahr, Fay és Dunbar (Klahr, Fay és Dunbar 1993) is. 


\section{A kisérletek tervezése}

A tudományos felfedezés létrejöttének egyik döntő szempontja olyan kísérletek tervezése, amelyek információval szolgálnak egy hipotézis érvényességének eldöntéséhez. Abban az esetben, ha egy tanulónak még nincs hipotézise, a jól megtervezett kísérletek használhatók a szimulációban használt modellre vonatkozó elgondolások generálására is. Klahr, Dunbar és Fay (Klahr, Fay és Dunbar 1991) a Big Trak (egy programozható robot) használatát kívánó környezetben számos sikeres heurisztikai eljárást ajánlanak. Egyszerû kísérletek tervezését kell kérni, hogy a tanulónak könnyú legyen megfigyelni a jelenséget. Olyan kísérleteket kell tervezni, amelyek jellegzetes eredményeket adnak, lehetôséget kell adni a koncentráláshoz a hipotézisek egy-egy dimenziójára, a meglepô eredmények hasznosítására és a hipotézisek erejének felhasználására a kísérleti stratégiák kiválasztásában (Klahr et al. 1991:388-391). Az irodalomban számos olyan jelenséget találunk, amelyek rámutatnak a rosszul megtervezett kísérleteket alkalmazó tanulók teljesítményének problémáira.

Az első ilyen jelenség a visszaigazolási elfogultság, az a tendencia, hogy a tanulók olyan információt keresnek, ami megerôsíti a hipotézisüket, ahelyett, hogy igyekeznének az ellenkezôjét bizonyítani. Egy klasszikus kísérlet keretében Watson (Watson 1960) visszaigazolási elfogultságot talált egy szabály felfedezéséról szóló feladatban, ahol a megerősítố bizonyíték nem a legjobb alkalmazható stratégia volt (Klayman-Ha 1987). Dunbar (Dunbar 1993) kimutatta, hogy szimulációs környezetben egyes tanulók erôsen hajlanak arra, hogy a hipotézisüket alátámasztó bizonyítékot keressenek, és hogy ez a hajlam megakadályozhatja ôket alternatív hipotézisek felállításában még akkor is, amikor ellentmondó bizonyítékokkal szembesülnek. Az influenzajárvány terjedéséról szóló szimulációs kísérletükben Quinn és Alessi (Quinn-Alessi 1994) úgy találták, hogy a tanulók meglehetősen ritkán (a 179 alanyból álló minta egyhatod részében) vezették le a kísérleteket avval a céllal, hogy megcáfoljanak egy-egy hipotézist. A kísérlet során arra kérték a tanulókat, hogy a kísérlet célját egy sor alternatíva közül válasszák ki a kísérlet lefolytatása elôtt.

A második jelenség olyan esetekben fordul elő, amikor a tanulók nem meggyőzoó kísérleteket terveznek. Erre a legjobban ismert példák egyike Watson kártyafordító kísérlete (Watson 1966). Ez a jelenség, ami analóg a visszaigazolási elfogultsággal, arra utal, hogy a tanulók nem mindig viselkednek „logikus gondolkodóként” és nem teszik meg a leghatásosabb lépéseket annak érdekében, hogy kipróbáljanak egy-egy hipotézist. A szimuláció segítségével történő felfedezéses tanulást illetôen Glaser és tsai (Galser et al. 1992) rámutatnak arra a gyakran megfigyelt jelenségre, hogy a tanulók hajlamosak túl sok változót variálni egyetlen kísérletben, aminek eredményeként ezekből a kísérletekből nem tudnak levonni semmiféle következtetést. Reimann (Reimann 1991) az optika területén megfigyelte, hogy a tanulók gyengén megtervezett kísérleteket végeznek, amelyek nem teszik lehetôvé egyértelmú következtetések levonását. Van Joolingen és De Jong két vizsgálatuk során (Van Joolingen-De Jong 1991b; 1993) úgy találták, hogy a tanulók gyakran terveznek olyan kísérleteket, amelyekben a változóknak semmi közük sincs a vizsgált hipotézishez. Az eredményes kísérletek százalékaránya ilyenkor alacsony, akár mindössze $22 \%$ is lehet. Shute és Glaser (Shute-Glaser 1990), valamint Schauble, Glaser és társai (Schauble, Glaser et al. 1991) beszámolói szerint a sikertelen tanulók nem gyújtenek elegendő adatot, mielőtt következtetéseket vonnának le. 
Egy harmadik jelenség az, hogy a tanulók elégtelen kísérletezôi viselkedést mutatnak. Kuhn és társai (Kuhn et al. 1992) például úgy találták, hogy a tanulók csak egy limitált készletet használtak fel a lehetséges informatív kísérletek teljes skálájából, és ráadásul többször megtervezték ugyanazt a kísérletet.

Egy negyedik típushoz a nem a hipotézis vizsgálatát célzó kisérletek tartoznak. Schauble, Klopfer és Raghavan (Schauble, Klopfer és Raghavan 1991) ezt az attitûdöt „mérnöki megközelítésnek” nevezték, mert egy kívánatos végeredmény megalkotására irányul, ahelyett, hogy próbálná megérteni a modellt. A mérnöki megközelítés - a tudományos megközelítéssel összehasonlítva - sokkal szúkebb kereséshez és azokra a változókra való koncentrációhoz vezet, amelyektốl siker várható. Következésképpen ez az attitűd megakadályozhatja a tanulókat olyan kísérletek tervezésében, amelyek jól kezelhetố adatokat nyújtanak, elegendő mennyiségben minden releváns kapcsolat felfedezéséhez az adott tárgykörben. Ezt a mérnöki megközelítést Schauble, Glaser, Duschl, Schulze és John (Schauble, Glaser, Duschl, Schulze és John 1995), valamint Njoo és. De Jong (Njoo-De Jong 1993a) is felismerték. Hasonló jelenséget talált White (White 1993) is, aki arról számolt be, hogy a tanulók - olyan kísérletek helyett, amelyek betekintést nyújtottak volna a modell struktúrájába - olyan kísérleteket terveztek, amelyek „szórakoztatóak” voltak számukra (a tanulók ekkor szimulációs játékokkal dolgoztak).

\section{Az adatok elemzése}

Amikor a tanulók elvégezték a megfelelố kísérleteket, szükség van az adatok értelmezésére, még mielőtt hipotéziseket alkothatnának a kísérleti eredmények alapján. Schauble, Glaser és társaik (Schaube, Glaser et al. 1991) szerint a sikeres tanulók jártasabbak abban, hogy az adatokban szabályszerúségeket fedezzenek fel, mint a sikertelen tanulók. Klahr és társai (Klahr et al. 1993) úgy találták, hogy a tanulók átlagosan 35\%-os arányban legalább egy esetben helytelenül kódolták a kísérleti adatokat, de - a konkrétan alkalmazott szabály típusától függôen - előfordult 63\%-ban helytelen kódolás is. Klahr és társai (Klahr et al. 1993:114) szerint „a kétértékű visszacsatoláshoz képest, amit a vizsgálati alanyok a tipikus pszichológiai kísérletek során kapnak, a valóságos világ adatainak értékelése kevésbé egyértelmû”. Az adatok félreértelmezésének esetében ez legtöbbször a felállított hipotézis megerősítéséhez vezetett, jelezve, hogy az alanyt saját hipotézise irányíthatja az adatok értelmezésében (ld. még Chinn-Brewer 1993; Kuhn et al. 1992).

A diagramok értelmezése, amire gyakran szükség van a szimulációs munka során, szintén bonyolult folyamat. Linn, Layman és Nachmias (Linn, Layman és Nachmias 1987) „mikroszámítógépes laboratóriumokban” (microcomputer-based laboratories - MBL) dolgozó és hagyományos osztályokban oktatott tanulók teljesítményét hasonlították össze. Az $M B L$ csoportban a tanulók a hőtan területén végeztek kísérleteket. Ezeknek a kísérleteknek a kimenete dinamikusan generált grafikonok formájában volt megadva. Linn és társai (Linn et al. 1987) úgy találták, hogy a tanulók grafikon-készítő képessége az $M B L$ csoportban a laboratóriumi munka következtében javult, de a bonyolultabb grafikonok esetében (például különböző grafikonok összehasonlításánál) az $M B L$ kurzus után is fennmaradtak a nehézségek. Mokros és Tinker 
(Mokros-Tinker 1987) számítógépes laboratóriumokba helyezték a tanulókat, ahol kísérletek alapján grafikonokat generálhattak, és arra biztatták ôket, hogy grafikus formában készítsenek elốrejelzéseket. Úgy találták, hogy a grafikonok értelmezésének a problémái, amelyek kezdetben előfordultak a gyerekeknél, gyorsan megszűntek.

\section{A felfedezéses tanulás szabályozása}

A szabályozási módszereket illetốen többen arról számolnak be, hogy a sikeres tanulók szisztematikusan tervezik meg és ellenőrzik kísérleteiket, míg a sikertelen tanulók nem szisztematikus módszerekkel dolgoznak (lásd pl. Lavoie-Good 1988; Simmons-Lunetta 1993). Shute és Glaser (Shute-Galser 1990) szintén azt állítják, hogy a sikeres tanulók gondosabban tervezik meg kísérleteiket és múveleteiket, és több figyelmet fordítanak az adatkezelési kérdésekre. Glaser és társai (Glaser et al. 1992) megemlítik, hogy a sikeres felfedezők a kísérletek során mindvégig követték elôzzetes tervüket, míg a sikertelenek inkább véletlenszerû stratégiát használtak és az alkalmi döntésekre koncentráltak, ami az addig elvégzett munka ellenőrzésében is problémákat okozott nekik (ld. még Scauble, Glaser et al. 1991). Bár Glaser és társai (Glaser et al. 1992) is jelzik, hogy a kitartás a jó tanulók tulajdonsága, vizsgálatuk során a sikeres diákok is készek voltak elhagyni egy utat, amikor úgy tûnt, hogy az nem vezet sikerre. Charney, Reder és Kusbit (Charney, Reder és Kusbit 1990) alacsony szintû elôzetes tudással rendelkezô tanulók esetében a cél kitûzését is problémaként említik. Általánosabb értelemben Veenman és Elshout (Veenman-Elshout 1995) úgy találták, hogy a jobb intellektuális képességủ tanulók jobb munkamódszert alkalmaznak, mint a gyengébb képességúek, de a tanulás eredményét a munkamódszer jobban befolyásolja, mint a szellemi képességek. A monitorozás során Lavoie és Good (Lavoie-Good 1998) a sikeres és sikertelen tanulók között olyan különbségeket találtak, hogy a jó tanulók többet jegyzetelnek tanulás közben, Schauble, Glaser és társaik (Schaube, Glaser et al. 1991) pedig - ugyancsak a sikeres tanulók estében - rendszerezettebb adatfelvételt állapítottak meg.

\section{A ssimuláció kombinálása oktatási segitséggel}

Az előző részben számos jellegzetes problémát mutattunk be a tudományos felfedezéses tanulás körébôl. Ezeket a problémákat számos kutató és tervező megfigyelte, akik - a fogalmak felfedezéses tanulásának kutatása terén elért eredményekkel összhangban (lásd pl. Mayer 1987) - különféle segítségnyújtási módszereket dolgoztak ki a szimulációval történô tanuláshoz. Tanulmányunknak ebben a részében összefoglalást adunk számos módszerról, amelyek segítik a tanulókat a felfedezési folyamatban. A segítség első eszköze, amivel foglalkozunk, az adott tárgykör információihoz való közvetlen hozzáférés biztosítása a tanulók számára. A továbbiakban olyan segítő lépéseket mutatunk be, amelyeknek az a céljuk, hogy egyes speciális felfedezési folyamatok végigjárásához nyújtsanak támogatást a tanulóknak. 


\section{Közvetlen hozzáférés az adott tárgykörhöz tartozó ismeretekhez}

Gyakran szóvátett igény a szimulációk alkalmazásánál, hogy a tanulóknak előzetes tudással kell rendelkezniük ahhoz, hogy a felfedezéses tanulás ereményes legyen. Az elégtelen elôzetes tudás lehet az oka annak, ha a tanulók nem tudják, milyen hipotézist állítsanak fel, nem tudják jól értelmezni az adatokat vagy rendszertelen kísérletezôi viselkedésre hajlanak (Glaser et al. 1992; Schauble, Glaser et al. 1991). Segítő lépésként számos szerző lehetővé tette a tanulók számára, hogy valamilyen gyakran többé-kevésbé kifinomult hipertext vagy hipermédia - formában hozzáférhessenek további információkhoz is a szimulációs környezetben (Glaser, Raghavan és Schauble 1988; Lajoie 1993; Shute 1993; Thomas-Neilson 1995). Shute (Shute 1993) leír egy olyan szimulációs környezetet, amelynek a használatakor a tanulók az elektromosság különféle alapvetô fogalmainak (pl. amper, töltés, hálózat, áram stb.) a definícióit ismerhették meg oly módon, hogy egy menüból kiválasztottak egy kifejezést, majd hipertext linkeket követtek. Shute (Shute 1993) összetett utóteszttel mérte az elméleti tudást és a problémamegoldási képességeket, s az így kapott eredmények alapján megállapította, hogy ennek az on-line elérhetố hipertext „szótárnak” pozitív hatása volt. Számos szerző rámutat arra, hogy az információ hozzáférhetővé tételének időzítése kritikus fontosságú tényező. Berry és Broadbent (Berry-Broadbent 1987) úgy találták, hogy sokkal hatásosabb abban a pillanatban nyújtani az információt, amikor arra szüksége van a tanulónak, mint minden szükséges információt átadni még a szimulációs munka elő́tt. Leutner (Leutner 1993) egy viszonylag összetett mezôgazdasági rendszer szimulációját használta vizsgálatában - itt a tanulók feladata a mezőgazdasági termelés optimalizálása volt. Leutner egyszer a szimulációs tevékenység előtt adta át a tanulóknak az információt (ami a szakterülethez tartozó fogalmakból, tényekbőll, szabályokból és elvekból állt), egy másik alkalommal pedig a szimulációs munka közben nyújtott háttér-információt a rendszer változóiról. Úgy találta, hogy a munka során állandóan rendelkezésre álló információ segített a tanulóknak a tárgyhoz tartozó ismeretek (fogalmak, szabályok és elvek) elsajátításában, de a szimuláció elốtt nyújtott információ nem volt hatásos. A funkcionális tudás megszerzését (az adott esetben a szimulációs eredmények optimalizálását) tekintve Leutner ugyanezt a mintát találta, de itt az eredmények kevésbé közvetlenek, mivel az információ átadását a szimuláció elốtt, illetve a szimulációs munka közben is kombinálták a többé-kevésbé bonyolult kísérletek elvégzését segítő tanácsokkal. Elshout és Veenman (Elshout-Veenman 1992) is arról számolnak be, hogy azok a tanulók, akik még az elốtt kaptak kiegészítô információkat a tárgyra vonatkozóan, hogy dolgoztak volna a szimulációs környezetben, nem profitáltak ebból.

Információ nemcsak a tanulási környezetből szerezhető, hanem előhívható a tanulók emlékezetéből is. Segítő lépések stimulálhatják a tanulókat, hogy elôzetes tudásukat egybevessék a kísérleti eredményekkel. Ennek elérése érdekében Lewis, Stern és Linn (Lewis, Stern és Linn 1993) elektronikus jegyzetelési lehetőséggel látták el a tanulókat, hogy lejegyezhessék azokat a „mindennapi élő példákat”, amelyeket a termodinamikai jelenségeket szimuláló környezetben megfigyeltek. 


\section{Segitség a hipotézis-alkotáshoz}

A hipotézis kidolgozása a felfedezéses tanulás egyik központi feladata. Ezzel kapcsolatban a tanulók számos vizsgálat során kaptak segítséget problémáik megoldásához. Schute és Glaser (Schute-Glaser 1990) a Smithtown elnevezésû számítógépes környezetben egy hipotézis-menüt kínált segítségképpen a hipotézis-alkotáshoz. A menü négy ablakból állt, amelyekben a hipotézis elemeit (a változókat, a változást kifejező igéket, és az összefüggések kifejezéseit) lehetett variálni. A segítségnyújtásnak egy másik, hasonló eszköze az ún. „hipotézis-jegyzetblokk” (Van Joolingen-De Jong 1991b; 1993). Ennél a megoldásnál a tanulók a változókat, a kapcsolatokat és a feltételeket választhatják ki két ablakból. Mindkét módszer a hipotézisek elemeit adja meg a tanulóknak, amelyekból nekik maguknak kell összeállítaniuk a saját hipotézisüket. Közvetlenebb segítséget ad a hipotézis-alkotáshoz a CIRCSIM-TUTOR környezet (Kim, Evans, Michael és Rovick 1989), amelyet az egészségügyi képzés területén a vérnyomással kapcsolatos problémák szimulációjára dolgoztak ki. Itt a diákoknak az a feladatuk, hogy kvalitatív előrejelzéseket tegyenek arról, hogy bizonyos feltételek esetén mi fog történni a kardio-vaszkuláris rendszer hét összetevőjével. Ahhoz, hogy ezt le tudják írni, a tanulók elốre kidolgozott ûrlapokat kapnak. Még egy lépéssel több segítséget jelent, ha kész hipotézisek állnak a tanulók rendelkezésére. A Pathophysiology Tutor (PPT) elnevezésú kórélettani oktató programban (Michael, Haque, Rovick és Evens 1989) a tanulók elôre meghatározott kórélettani hipotézisek közül választhatnak, ezeket menükbe rendezett listák tartalmazzák. Njoo és De Jong (Njoo-De Jong 1993a; 1993b) hasonló módszereket használtak. Kiderült, hogy előre meghatározott hipotézisek alkalmazása pozitívan befolyásolja a tanulási folyamatot és a tanulók teljesítményét. Quinn és Alessi (Quinn és Alessi 1994) arra kötelezték a tanulókat, hogy a szimulációs feladatoknál a kísérletek elvégzése előtt írják le a legvalószínúbb hipotézist vagy válasszanak ki több valószínű hipotézist. Itt az elgondolás lényege az, hogy több rendelkezésre álló hipotézis elhagyásos vagy szelekciós stratégiához vezet, ami jobb lehet, mint ha a tanulók egyszerre csak egy hipotézisre koncentrálnak. Quinn és Alessi adatai azt mutatták, hogy a több hipotézises stratégia valóban jobb teljesítményhez (a szimulált rendszer megkívánt állapotának eléréséhez) vezetett, de csak akkor, ha a szimuláció nem volt túlságosan bonyolult. A szimuláció bonyolultságának magasabb szintjein a több hipotézises startégiának semmi előnye nem volt az egyetlen hipotézises stratégiával szemben. Lehetséges, hogy a több hipotézises stratégia hatékonyságát növelte az a tény, hogy az egyik változónak intuícióellenes hatása volt.

\section{Segitség a kisérletek tervezéséhez}

A tanulók segítése érdekében a tanulási környezet burkolt kísérletezési útmutatásokat is adhat a kísérletek tervezéséhez. Rivers és Vockell (Rivers-Vockell 1987) közöl néhány ilyen „tippet” és célzást (pl. „bölcs dolog egyszerre csak egy változót variálni”). Rivers és Vockell ilyen általános jellegû, burkolt kísérletezési útmutatásokkal látták el a tanulókat, mielőtt azok hozzákezdtek a számítógépes szimulációs feladatokhoz. Ez nem befolyásolta a tanulási eredményt, de hatással volt a diákok kísérle- 
tezési képességeire. Az útmutatásokat dinamikusan is lehet adni, a tanulók kísérletezési viselkedése alapján. Ha a tanuló nem optimális tanulási viselkedést mutat, útmutatással segítik tovább. Ilyen típusú útmutatásokat tartalmaz például a Smithtoren rendszer (Schute-Glaser 1990). Leutner (Leutner 1993) tanulmányozta annak hatását, ha a tanulók ilyen típusú adaptációs tanácsokat kapnak, és úgy találta, hogy ha a tanácsok korlátozott jellegúek, ez hozzájárul a tanulók tárgyi ismereteinek bővüléséhez az adott témakörben, de akadályozza a funkcionális tudás megszerzését. A tanácsok több részlettel való kiegészítés után segítettek a funkcionális tudás növelésében is, bár a hatás itt kevésbé világos, mivel a segítséghez hozzátartozott a tárgyra vonatkozó további információk megadása is.

\section{Segitség elörejelzések kidolgozásához}

Míg a hipotézis valamilyen állítás a változók között fennálló kapcsolatokról egy elméleti modellben, az előrejelzés arra vonatkozó állítás, hogy egy függő változó a független változó(k) értékeinek függvényében milyen - a szimulációban megfigyelhető - értékeket fog felvenni. A tanulókat azzal segíthetjük előrejelzéseik megfogalmazásában, ha adunk nekik valamilyen eszközt, melynek segítségével rajzolhatnak egy görbét, ami ábrázolja a szóbanforgó függvénykapcsolatot. Lewis és társai (Lewis et al. 1993) ilyen grafikus ábrázoló eszközzel látták el a tanulókat. A tanulók visszajelzést is kaptak előrejelzéseik pontosságáról: a helyes görbét utólag feltüntették ugyanazon a diagramon, mint ami a szimulációt végző tanuló előrejelzését mutatta. Tait (Tait 1994) is leír egy hasonló mechanizmust, de az ô esetében a visszajelzés magyarázatokat is tartalmazott a rendszer valós állapotát mutató görbe és a tanuló által megadott görbe között mutatkozó eltérésekról. A Reimann (Reimann 1991) által vizsgált, fénytörési jelenségeket szimuláló környezetben a tanulók lehetôséget kaptak arra, hogy három különbözô pontossági szinten: a számszerû adatok, a grafikus ábrázolás és a görbe által a diagramon elfoglalt hely megadásának szintjén tegyenek előrejelzéseket.

\section{A regulativ tanulási folyamatok elösegitése}

A tanulást a regulatív folyamatok irányítják. A szabályozástól függó és a szabályozottság mértékét tükröző sajátosságok - például a „tervezettség” és a „szisztematikusság” - a sikeres felfedezéses tanulás központi fontosságú jellemzőinek minôsülnek (Glaser et al. 1992; Schauble et al. 1995). A két legfontosabb regulatív folyamat a tervezés és a monitorozás (De Jong-Njoo 1992). Mind a tervezést, mind a monitorozást segíti, ha a szimulációs környezetben lehetőség van a modell kialakulásának bemutatására. A modell kidolgozási lépéseinek megismerése egyúttal konkrét segítséget ad a tervezéshez és a monitorozáshoz is. Végül a felfedezéses folyamat strukturálása is segítheti a regulatív folyamatokat.

A modell fokozatos felépitése. Ennek a módszernek az az alapvetố gondolata, hogy túlságosan „lehengerlő” élmény lehet, ha a tanuló hirtelen, egy csapásra kerül szembe a szimulációs környezet teljes összetettségével, tehát jobb, ha a modellt folyamatosan, lépésrốl lépésre építik fel. A modell fokozatos felépitésének alkalmazására White és 
Frederiksen (White-Frederiksen 1989; 1990) QUEST környezetben végzett munkája az egyik legismertebb példa. A QUEST elektromos rendszerekkel foglalkozik. Az elektromos áramkörök modelljei a QUEST-ben eltérőek lehetnek jellegükben (minőségi vagy mennyiségi modellek), bonyolultsági fokozatukban (a változók számát és a változók közti viszonyokat tekintve), valamint funkcionális, illetve fizikai perspektívájukban is. A QUEST környezetben való tanulás során a tanulók olyan modellekkel találkoznak, amelyek minőségi természetűből mennyiségi jellegűvé fejlődnek tovább, egyre bonyolultabbá válnak vagy funkcionális perspektívájuk fizikai perspektívává alakul át. Ilyen módon a tanítási és a tanulási folyamat követi a (feltételezett) átmenetet egy kezdő tudásától a szakember szintjéig. A QUEST környezet ellenőrzött értékelésére tudomásunk szerint eddig még nem került sor. Swaak, Van Joolingen és De Jong (Swaak, Van Joolingen és De Jong 1996) a modellfejlődést abban az esetben tanulmányozták, amikor a modell összetettsége növekszik. A harmonikus rezgéseket szimuláló SETCOM környezetben a modell a szabad rezgésektôl a tompított rezgéseken keresztül a külsố erô hatásával módosított rezgésekig fejlődik.

Tervezési segitség. A tervezési segítség Charney és társai (Charney et al. 1990) szerint kiemelkedően hasznos lehet az alacsony szintû tudással rendelkezố tanulók számára. Ha a tervezéshez nyújtunk segítséget, a tanulókat megfosztjuk a döntés lehetôségétôl, ám ez segít nekik a tanulási folyamat irányításában. A tervezéshez különbözố módokon nyújtható segítség. A szimulációknak a tudományos felfedezéses tanulás terén való alkalmazását illetôen Showalter (Showalter 1970:49) már igen korán javasolta kérdések felhasználását a tanulók vezetésére a felfedezés folyamatában. Kérdései (pl. „elérhetnek-e a patkányok egy olyan pontot, ahol már nem tanulnak többet?”) a tanulók figyelmét a szimuláció konkrét aspektusaira irányították. Zietsman és Hewson (Zietsman-Hewson 1986) hasonló típusú kérdéseket alkalmazott a sebesség tanulmányozására szolgáló szimulációban, Tabak, Smith, Sandoval és Reiser (Tabak, Smith, Sandoval és Reiser 1996) pedig azzal a szándékkal tettek fel ilyen kérdéseket, hogy egy biológiai tárgyú szimulációban célokat tüzzenek ki. White (White 1984:78-81) a newtoni mechanika szimulációjában játékok bevezetésével segített a tanulóknak célokat kitűzni. A játékok White módszerével egy bizonyos szimulációs állapot elérésére ösztönzik a tanulókat (például arra, hogy a szimulációban ,juttassák el az úrhajót a kanyaron túlra, anélkül, hogy falba ütközne). Egyik kísérletében White úgy találta, hogy azok a tanulók, akik játékokat tartalmazó szimulációval tanultak, teljesítményükkel túlszárnyalták azokat a tanulókat, akik minőségi problémákkal foglalkozó feladatokban („Mi történne, ha...?” vagy „Hogyan lehetne elérni...?” típusú kérdésekre válaszolva) egyszerú szimulációval dolgoztak. A ThinkerTools környezet is hasonló összefüggésben használja fel a játékokat (White 1993). De Jong és társai (De Jong et al. 1994) különböző típusú feladatokat írnak le, amelyeket szimulációkkal kombinálva lehet alkalmazni. A kutatási jellegú feladatok arra buzdítják a tanulókat, hogy megtalálják a kapcsolatot két vagy több változó között. A specifikációs feladatok egy bizonyos változó értékének becslésére szólítják fel a tanulókat. Az explikatív jellegú feladatok megoldása során a tanulók a szimulációs környezet egy bizonyos jelenségének a magyarázatát adják meg. De Jong és társai (De Jong et al. 1995) ütközések szimulációjában, Swaak és társai (Swaak et al. 1996) a harmonikus rezgés szimulációjában, De Jong, Härtel, Swaak és Van Joolingen (De Jong, Härtel, Swaak és Van 
Joolingen 1996) pedig a villamos távvezetékek szimulációjában arra a megállapításra jutottak, hogy a tanulók, akik szabadon választhattak a feladatok közül, nagyon gyakran megoldották ezeket, és a feladatok megoldása pozitív hatással volt az úgynevezett „intuitív tudás” megszerzésére.

Monitorozás útján nyújtott segitség. Saját felfedezési folyamataink áttekintését segíti, ha tudjuk, mi történt a szimulációs környezetben. Reimann (Reimann 1991) a Refract környezetben a kísérletekből származó számszerú és névleges adatok tárolására elektronikus ,jegyzetfüzetet” bocsátott a tanulók rendelkezésére. A ,jegyzetfüzetben" az adatok úgy voltak manipulálhatók, hogy a kísérleteket egy bizonyos változó értékeinek alapján lehetett szortírozni és ki lehetett választani azokat a kísérleteket, amelyekben egy bizonyos változó egy bizonyos értéket vett fel, a kísérletek alapján pedig fel lehetett állítani egy egyenletet. A tanulók a ,jegyzetfüzetből” újra le tudtak játszani egyes kísérleteket. Hasonló jegyzetelési eszközöket biztosít a Smithtown (Schute-Glaser 1990) és a Voltaville (Glaser et al. 1988) szimulációs környezet is. A SHERLOCK környezetben a tanulók - saját kérésükre - áttekintést kaphatnak az addig megtett lépéseikről (Lesgold, Lajoie, Bunzo és Eggan 1992). Schauble, Raghavan és Glaser (Schauble, Raghavan és Glaser 1993) olyan monitorozási segítséget vezetett be, amely nemcsak áttekintést adott a tanulók lépéseiről, hanem bizonyos célok esetén csoportos akciókhoz is megadta ezt a lehetôséget, és a tanulók kérhettek „szakértői véleményt" is, ami rámutat lépéseik relevanciájára a konkrét célhoz (pl. a két változó között fennálló kapcsolatok felfedezéséhez) viszonyítva. Ez a fajta segítség kombinálja a monitorozási és a tervezési segítséget. A tanulóknak valamennyi itt bemutatott példában maguknak kell kiválasztaniuk az összehasonlítandó korábbi kísérleteket a kísérletek teljes készletéből. Reimann és Beller (Reimann-Beller 1993) ehhez a CABAT rendszert javasolják, amely hasonlóság alapján választ ki korábbi kísérleteket a készletbőll, s ezeket összehasonlításra felkínálja a tanulóknak.

A felfedezés folyamatának strukturálása. A regulatív folyamatokat lehet segíteni továbbá úgy is, hogy a tanulókat végig vezetjük a folyamat különbözô fázisain. A „strukturált” környezetekben az útmutatások gyakran több más lépéssel kombinálódnak - ezeknek a hatását számos tanulmány hasonlítja össze a „strukturálatlan” környezetekével. Linn és Songer (Linn-Songer 1991) úgy találták, hogy a tanulók ellátása a kísérleti lépések megtételére vonatkozó utasításokkal (például „a kísérlet elvégzése elôtt...” „most végezzék el a kísérletet...”, „a kísérlet elvégzése után...”), továbbá a részletesebb útmutatás minden egyes lépés alkalmával hatékonynak bizonyult. Így - a strukturálatlan környezethez képest - legalább kétszer, esetenként négyszer annyi tanuló volt képes megkülönböztetni az adott terület központi fogalmait (hő és hőmérséklet). Njoo és De Jong (Njoo-De Jong 1993b) egy szimulációs kísérlet során gépészmérnök hallgatóknak olyan ûrlapokat adtak, amelyeken külön rubrikák voltak a következốk feljegyzésére: változók és paraméterek, hipotézis, kísérlet, előrejelzés, adatértelmezés, konklúzió. Egy teszt alkalmából, amely a „kvalitatív megértést” mérte, ez a „strukturált” csoport jobban teljesített, mint az a csoport, amely kiegészítô anyagok nélkül dolgozott a szimulációs környezetben.

Gruber, Graf, Mandl, Renkl és Stark (Gruber, Graf, Mandl, Renkl és Stark 1995) egy közgazdasági szakiskola 60 tanulójából álló vizsgálati mintájuk egyik felében a tanulóknak azt az utasítást adták, hogy tegyenek elốrejelzéseket, azokat hasonlítsák ös- 
sze az eredményekkel és vonják le a következtetéseket. A minta másik felében a tanulók nem kaptak útmutatást. Az itt használt szimuláció közgazdasági tárgyú volt: egy ruhagyár profitját kellett maximalizálni. Egy tudásmérố tesztben, amelyben a tanulóknak új helyzetekben kellett előrejelzéseket tenniük, a vezetett csoport jobb teljesítményt nyújtott, mint a nem vezetett csoport.

White (White 1993) ThinkerTools környezetben arra kérte a tanulókat, hogy egy négy fázisból („kérdésfeltevésből, a kísérlet elvégzéséből, a törvények megfogalmazásából és az általánosítások megvizsgálásából”) álló cselekvéssorozatot kövessenek, részletes útmutatást adva minden egyes fázishoz (White 1993:53). Egy olyan tesztben, amely kvalitatív előrejelzések helyességét mérte a valóságból vett konkrét helyzetek példáin, White a szimulációra épülő oktatást egyértelmúen eredményesebbnek találta a hagyományos tanterv szerint folyó tanításnál.

Veenman és Elshout számos kísérletben hasonlította össze a „strukturált” és a „strukturálatlan” szimulációs környezetben dolgozó tanulók tanulási magatartását és eredményeit. A „strukturálatlan” szimulációban a vizsgálati alanyok nem kaptak semmiféle útmutatást. A strukturált („meta-kognitív eszközökkel gazdagított”) környezetben a tanulók különféle feladatokat kaptak és a kutatók arra bíztatták ôket, hogy „fogalmazzák át a kérdést, alkossanak hipotézist, dolgozzanak ki részletes akciótervet és a végrehajtásról készítsenek jegyzeteket”. Miután elvégeztek egy lépéssorozatot, arra kérték ôket, hogy „értékeljék kísérleti eredményeiket” és „a következtetés levonásakor jegyzeteik felhasználásával fejtsék ki a témát” (Veenman, Elshout és Busato 1994:97). A fogalmi tárgykört itt egyszerű elektromos áramkörök, valamint hőelméleti és statisztikai témák alkották. Veenman és Elshout (Veenman-Elshout 1995) vizsgálatuk adatainak átfogó elemzésében nem tudták kimutatni a környezet strukturálásának általános hatását. Részletesebb vizsgálati szinten azonban bizonyítékot találtak arra, hogy az alacsonyabb intelligenciájú és szegényes munkamódszerú tanulók profitálnak a környezet strukturálásából, ez azonban az alacsony intelligenciájú, de jó munkamódszerű tanulóknál nem igaz és szintén nem igaz a magas intelligenciájú tanulók esetében sem, függetlenül a munkamódszertôl. Ebben a sok szempontra kiterjedő elemzésben a teljesítmény számos mérési módjával (például tényszerû tudástesztekkel és problémamegoldó feladatokkal) kapott eredményeket egyetlen teljesítményjelzô mutatóban kombinálták.

Két olyan tanulmányt találtunk, amelyek a strukturált szimulációs környezetben, illetve hagyományos kifejtéses módszerrel folytatott oktatás összehasonlításáról számoltak be. Lewis és társai (Lewis et al. 1993) azt kívánták a tanulóktól, hogy a kisérletek elvégzése előtt tegyenek előrejelzéseket, a kísérlet után pedig grafikus formában hasonlítsák össze a változókat és írják le következtetéseiket. Arra ösztönözték a tanulókat, hogy írjanak le „mindennapi példákat”, „fontos kérdéseket” és „példákat a fogalmakra", s jegyezzenek fel mindent, ami számukra esetleg nem volt világos (Lewis et al. 1993:48). A jegyzetelés elektronikus formában történt. Lewis és társai megállapították, hogy azokra a kérdésekre, amelyeknek a megválaszolásához szükség volt a hő és a hőmérséklet fogalma közötti különbség lényegének a megértésére, a szimulációba résztvevổ tanulók nagyobb százalékos arányban adtak helyes válaszokat, mint azok a társaik, akik az előzó évben a hagyományos tantervet követték. A Smithstown környezetben (Shute-Glaser 1990) a tanulókat „kézenfogva” vezetik vé- 
gig a lépések előre rögzített sorozatán, ami kissé kevésbé szigorú például a Lewis és társai (Lewis et al. 1993) által alkalmazott sorrendnél. A Smithstown környezetben is megkérik a tanulókat, hogy tegyenek előrejelzéseket, de ez nem kötelezó számukra. A Smithstown környezet nemcsak strukturált, hanem számos más segítő és gazdagító elemet is tartalmaz. Egy értékelés során a fogalmak felidézését mérő teszt nem mutatta ki, hogy a szimulációval folytatott tanulás előnyösebb lenne a hagyományos óráknál, bár a Smithstown környezetben folyó tanulás egyébként sokkal hatékonyabb volt.

\section{Összegzés és következtetések}

Tanulmányunkban áttekintést adtunk azokról a kutatásokról, amelyeknek témája a tudományos felfedezéses tanulás fogalmi területeinek számítógépes szimulációja. A felfedezéses tanulási folyamatot empirikusan vizsgáló tanulmányokból levonhatjuk azt a következtetést, hogy a sikeres felfedezéshez számos speciális képességre van szükség. Általában elmondható, hogy a sikeres felfedezéses tanulás feltételezi a hipotézisből kiinduló okfejtést, a tervszerű, szisztematikus eljárást (például a változók értékeinek szisztematikus variálását), a felfedezés folyamatában és jó heurisztikai módszerek használatát a kísérlet során. Ezek a képességek lehetnek általánosak, de szorosabban is kapcsolódhatnak egy-egy tudományterülethez (Glaser et al. 1992).

A felfedezési folyamat számos jellegzetes problémáját sikerült meghatározni. A hipotézis-alkotásnál hiba az olyan hipotézisek választása, amelyek „biztonságosnak” tűnnek, továbbá hiba az is, ha az adatokat nem megfelelően transzformálják hipotézissé, akár megerôsítô, akár nem megerősítő adatokról van szó. A kísérletek tervezését illetốen találtunk beszámolókat olyan tanulókról, akik következetlen kísérleteket terveznek, hatástalan kísérletezési viselkedést mutatnak, visszaigazolási elfogultságot követnek vagy a tudományos módszer helyett mérnöki megközelítést alkalmaznak. A tanulóknak igen gyakran jelent problémát az adatok értelmezése. További gond, hogy a tanulók nem igazán képesek szabályozni a tanulási folyamatot, ami kifejeződik strukturálatlan viselkedésükben, vagyis úgy nyilvánul meg, hogy átfogó terv nélkül sodródnak és alkalmi döntéseket hoznak. Ez megmutatkozik a tanulási folyamat elégtelen monitorozásában is.

Megvizsgáltuk a szimulációval együtt alkalmazott segítô oktatási eszközöket is. A kutató pedagógusok számos módszerrel adnak különféle útmutatásokat a tanulóknak - ezek közül több még csak a kidolgozási fázisban van, s a kiegészítő oktatási beavatkozás hatását eddig még nem értékelték ellenőrzött módon. Más vizsgálatok során, amelyeknél már történ megbízható értékelés, többféle segítô eszköz kombinációit használták, s így az egyes konkrét lépések hatását lehetetlen volt kinyomozni. A fennmaradó tanulmányok alapján háromféle kiegészítő jellegú segítő lépés ígér pozitív hatást a tanulási eredményekre. Először is hatásosnak tûnik a tárgykörhöz tartozó információk közvetlenül elérhetôvé tétele a tanulók számára - abban az esetben, ha az információt a szimulációval egyidejúleg a kísérletek elvégzése közben is biztosítják, vagyis az információ mindig elérhetô a szükséges pillanatban. Másodszor, egyértelmúen jó hatással van a tanulási eredményre, ha a tanulókat feladatokkal (kérdésekkel, gyakorlatokkal vagy játékokkal) látják el. Harmadszor, azok a tanulók, akik a mo- 
dellek fokozatos felépítését is lehetôvé tevő környezetben tanulnak, jobb teljesítményt nyújtanak, mint azok, akik ugyanazt a környezetet kész, rögzített modellek alkalmazásával használják - bár úgy tűnik, hogy ennek a hatásnak az eléréséhez a modellnek megfelelően összetettnek kell lennie. Egyéb segítő lépések (például a hipotézisalkotáshoz nyújtott segítség, a kísérletezési útmutatások, a monitorozási eszközök és az előrejelzési segítség) hatásosságára nézve nincs elegendő alap általános következtetések levonásához. Végül, a környezet strukturálását illetően számos tanulmány azt mutatja, hogy ez hatásosabb tanuláshoz vezethet, mint a strukturálatlan környezet használata. Meg kell jegyeznünk azonban, hogy a környezet strukturálása mindezekben a vizsgálatokban nemcsak a tanulási folyamat megkülönböztetett lépésekre való felosztását foglalta magában, hanem más oktatási lépéseket is.

A tudományos felfedezéses tanulás egyik döntő fontosságú tényezője az az oktatási cél, amelynek elérésére használják. A felfedezéses tanulás eredeti koncepcióját követve gyakran állítják, hogy a tudományos felfedezéses tanulás olyan tudáshoz vezet egy tanuló ismeret-bázisában, ami intuitivabb és mélyebben gyökerező (Berry-Broadbent 1984; Laurillard 1992; Lindstöm, Marton, Ottosson és Laurillard 1993; Swaak-De Jong 1996), továbbá inkább minöségi karakterû (White 1993). Gyakran megfogalmazódik az a nézet is, hogy a szimuláció alapú tanulás eredményeit csak alkalmazási és átviteli tesztekkel lehet hitelesen mérni (Thomas-Hooper 1991:500). Erre az állításra Berry és Broadbent (Berry-Broadbent 1984) vizsgálatai szolgáltattak bizonyítékot, akik rámutattak, hogy míg a szimulációk hatásosan edzhetik a tanulók képességeit egy bizonyos szimulációs állapot elérésére, ez nem feltétlenül jelenti azt, hogy a területhez kapcsolódó fogalmi ismeretanyag elsajátítása is megtörtént. A „kifejthetô” (elméleti) tudás és a „funkcionális” (gyakorlati) tudás közti kapcsolat hiányosságait Anderson és Lawton (Anderson-Lawton 1992) egy üzleti tárgyú szimulációban, Flick (Flick 1990) a newtoni mozgás gyerekekkel végzett szimulációjában, McDermott (McDermott 1990) pedig kinematikai jelenségek szimulációjában mutatta ki. Ugyanezt mutatják a mechanikai ütközések (De Jong et al., 1995; Whitelock et al. 1993), komplex mezőgazdasági problémák (Leutner 1993), közgazdasági témák (Mandl, Gruber és Renkl 1994), a gyorsulás és a sebesség (Rieber et al. 1996; Rieber 1996), valamint a harmonikus rezgések (Swaak et al. 1996) területén végzett különféle szimulációs vizsgálatok is.

Áttekintésünkben bizonyítékot találtunk az „intuitív” vagy „mély” tudás fontosságára is a felfedezéses tanulásban. A szimulációt a kifejtéses tanítással összehasonlító vizsgálatok során Grimes és Willey (Grimes-Willey 1990) például olyan tesztet használtak, amely „észrevételt és megértést”, továbbá „explicit” vagy „implicit” alkalmazást kért számon. Kísérletükben a szimulációs csoport, amely általában is jobb eredményt ért el a kontroll csoporttal szemben, az implicit alkalmazást mérő feladatok esetében kifejezetten sikeresebb volt. Carlsen és Andre (Carlsen-Andre 1992) tanulmányában a szimulációs csoport az utóteszten nem ért el magasabb szintû́ eredményt, mint a nem szimulációval dolgozó csoport, de a tanulói megoldások mentális modelljének elemzésekor (a kiválasztott alternatívák értékelése alapján) kiderült, hogy a szimulációs csoport tanulóinak a modelljei fejlettebbek voltak. Rieber és társai (Rieber et al. 1990) speciális tesztekkel mérték az adott tárgykörre vonatkozó szabályok alkalmazásának képességét. Az utóteszt alkalmából a szimulációs csoport je- 
lentôsen kevesebb idôt töltött a kérdések megválaszolásával, mint a kérdésekkel erôsített különórán tanult csoport. Rieber és társai (Rieber et al. 1990) szerint ez mélyebben feldolgozott tudásra utal.

Úgy tûnik, hogy azoknak a kutatásoknak az eredményeiben, amelyek strukturált szimulációs környezeteket hasonlítanak össze strukturálatlanokkal vagy a normális tananyaggal, a tudásmérő teszt típusa is szerepet játszik. Linn és Songer (Linn-Songer 1991), valamint Lewis és társai (Lewis et al. 1993) a központi fogalmak minôségi megkülönböztetésének mérésére kidolgozott tesztet használtak, Njoo és De Jong a minőségi rálátást mérték, Gruber és társai (Gruber et al. 1995) és White (White 1993) pedig - akárcsak De Jong és társai (De Jong et al. 1995), valamint Swaak és társai (Swaak et al. 1996) - előrejelzéseket kérő teszteket használtak. Mindezek a tanulmányok a strukturált szimulációs környezetek előnyét mutatták. Veenman és Elshout (Veenman-Elshout 1995) a kvalitatív és a definitív tudás kombinációját tesztelték, és - egy bizonyos tanulócsoport kivételével - nem mutatták ki a környezet strukturálásának átfogó hatását. Végül, a Smithtown környezet értékelésénél (Shute-Glaser 1990) semmiféle különbség nem volt a strukturált szimulációs környezet és egy hagyományos óra hatékonysága között, de itt fogalmak felidézését mérô tesztet alkalmaztak. A szimulációk előnyei akkor látszanak világosan, amikor a cél a felfedezési képességek elsajátítása. Rivers és Vockell (Rivers-Vockell 1987) vizsgálatában nemcsak a tárgykörre vonatkozóan szerzett tudást, hanem a felfedezési képességeket is mérték egy sor általános teszttel (köztük Watson és Glaser kritikai gondolkodási tesztjével), és elemezték egy tudásmérố elôteszt pontszámainak tendenciáját is. Végkövetkeztetésük szerint a szimulációban résztvevô tanulók jobb eredményeket értek el, mint a kontroll-csoport tagjai, különösen akkor, ha a szimulációk tanácsok formájában olyan útmutatást is magukba foglaltak, ami az eredményes felfedezési viselkedés felé mutatott (ld. még Faryniarz-Lockwood 1992; Woodward, Carnie és Gersten 1988).

Jelenleg számos olyan környezet további fejlesztése folyik, amelyek a tanulókat önvezérelt (felfedezéses) tanulásra csábítják, és segítő eszközöket nyújtanak a tanulási folyamathoz (ld. például Suthers, Weiner, Connelly és Paolucci 1995). A kutatás elsődleges feladata ezen a téren nézetünk szerint azoknak a problémáknak a további mélyebb elemzése, amelyekkel a tanulók a felfedezéses tanulás során szembekerülnek, továbbá a tanulók konkrét segítési módjainak értékelése. A kutatásoknak elsősorban annak a vizsgálatára kellene irányulniuk, hogy mikor és hogyan kell a tanulókat ellátni olyan eszközökkel, amelyek pótolják hiányosságaikat a felfedezéses tanulás során, más szóval hogyan lehet „körülállványozni” a felfedezéses tanulási folyamatot. Az ilyen értékelési tanulmányoknál három további fontos kérdést kell figyelembe venni. Elôször is, újabb segédeszközök bevezetése nemcsak segíti a tanulókat bizonyos akciók véghezvitelében, hanem a kognitív túlterhelés megelózésére is használható (Glaser et al. 1988:63). Néhány segítő módszer mindazonáltal emelheti is a kognitív megterhelést, ha bonyolultabbá teszi a környezetet: Gruber és társai (Gruber et al. 1995) például rámutatnak, hogy a többszörös nézőpontok bevezetése a szimulációs környezetben a kognitív teher emelésével jár. A segítő lépésekre vonatkozó újabb kutatásoknál figyelembe kell venni a további segítséget nyújtó módszerek hatását a kognitív megterhelésre (ld. például De Jong et al. 1995; Swaak et al. 1996). 
A segédeszközök alkalmazásánál a második szempontként azt kell tudatosítaniuk magukban a tervezőknek, hogy ezeket az eszközöket a tanulási környezetekben nem zavaró módon is fel lehet használni segítségadásra, amint azt már a Voltaville tervezésekor Glaser és társai (Glaser et al. 1988) is megfigyelték. Például a SHERLOCK környezetben (Lesgold et al. 1992) a tanuló úgy halad végig a diagnosztikus problémamegoldó folyamaton, hogy lépések menüiből választ. Ez egyrészt segíti a tanulót a tervezési folyamatban, másrészt segíti a kutatót (illetve a rendszert) is a tanuló szándékainak felmérésében. A SHERLOCK környezetekben ez a „tervezési segédeszköz” a tanuló számára jól felhasználható, megfelelő tanácsok generálására szolgál. Van Joolingen (Van Joolingen 1995) leír néhány elvet arról, hogy az úgynevezett „hipotézis-jegyzetblokkban” összegyújtött információ hogyan használható a tanulók valódi tudásának felmérésére. A harmadik fontos feladat az, hogy meg kell vizsgálni a szimulációk helyét a tantervben. Lavoie és Good (Lavoie-Good 1988) piaget-i megközelítést javasolnak, ami annyit jelent, hogy a szimulációkat beiktatják a tantervbe már a tanulás első olyan fázisában, amikor a felfedezés lehetôvé válik, míg a fogalmakat formálisan csak késóbb vezetik be, és csak legvégül történik meg ezeknek az alkalmazása (ld. még Brant et al. 1991; White 1993). Ez a megoldás már a számítógépes szimulációk olyan lehetséges használatára utal, ami különbözik a klasszikus, hipotézisre épülő módszerektől.

Arra, hogy a szimuláción alapuló felfedezéses tanulás megtervezéséhez megfelelő elméleti alapok állnak rendelkezésünkre, majd csak akkor számíthatunk, amikor a tanulmányunkban vázolt problémákról már elegendô kutatási eredménnyel rendelkezünk. A jelenlegi kísérletek érdekesek ugyan, de egyelôre még szükségképpen töredékesek és befejezetlenek (ld. például Thurman 1993). A szimuláció útján történô felfedezéses tanulás - mint a technikai eszközökre épülő tanulási környezetekben alkalmazható új módszer, melyben nagyobb hangsúly kerül a tanulók önálló tevékenységére - a megalkotandó új elméleti bázisra épülve foglalhatja majd el méltó helyét az oktatás és a tanulás világában.

Váradi Kalmár Zsussanna fordítása

\section{IRODALOM}

Alessi, S. M. (1995): Dynamic vs. static fidelity in a procedural simulation. Paper presented at the Annual Meeting of the American Educational Research Association, San Francisco, CA.

Alessi, S. M. - Trollip, S. R. (1985): Computer based instruction: methods and development. Englewood Cliffs, N.Y.: Prentice-Hall.

Anderson, P. H. - Lawton, L. (1992): The relationship between financial performance and other measures of learning on a simulation exercise. Simulation \& Gaming, 23, 326-340.

Bangert-Drowns, R. - Kulik, J. - Kulik, C. (1985): Effectiveness of computer-based education in secondary schools. Journal of Computer Based Instruction, 12, 59-68.

Berry, D. C. - Broadbent, D. E. (1984): On the relationship between task performance and 
associated verbalizable knowledge. The Quarterly Journal of Experimental Psychology, 36A, 209-231.

Berry, D. C. - Broadbent, D. E. (1987): Explanation and verbalization in a computer-assisted search task. The Quarterly Journal of Experimental Psychology, 39A, 585-609.

Brant, G. - Hooper, E. - Sugrue, B. (1991): Which comes first: the simulation or the lecture? Journal of Educational Computing Research, 7, 469-481.

Bruner, J. S. (1961): The act of discovery. Harvard Educational Review, 31, 21-32.

Carlsen, D. D. - Andre, T. (1992): Use of a microcomputer simulation and conceptual change text to overcome students' preconceptions about electric circuits. Journal of Computer Based Instruction, 19, 105-109.

Chambers, S. K. - Haselhuhn, C. - Andre, T. - Mayberry, C. - Wellington, S. - Krafka, A. Volmer, J. - Berger, J. (1994, April): The acquisition of a scientific understanding of electricity: Hands-on versus computer simulation experience: conceptual change versus didactic text. Paper presented at the Annual Meeting of the American Educational Research Association, New Orleans, LA.

Charney, D. - Reder, L. - Kusbit, G. W. (1990): Goal setting and procedure selection in acquiring computer skills: A comparison of tutorials, problem solving, and learner exploration. Cognition and Instruction, 7, 323-342.

Chinn, C. A. - Brewer, W. F. (1993): The role of anomalous data in knowledge acquisition: A theoretical framework and implications for science instruction. Revierw of Educational Research, 63, 1-51.

Coleman, T. G. - Randall, J. E. (1986): HUMAN-PC: A comprehensive physiological model. Computer software, J. Jackson: University of Mississippi Medical Center.

diSessa, A. - Abelson, H. (1986): Boxer: a reconstructible computational medium. Communications of the ACM, 29, 859-868.

Dunbar, K. (1993): Concept discovery in a scientific domain. Cognitive Science, 17, 397-434.

Elshout, J. J. - Veenman, M. V. J. (1992): Relation between intellectual ability and working method as predictors of learning. Journal of Educational Research, 85, 134-143.

Faryniarz, J. V. - Lockwood, L. G. (1992): Effectiveness of microcomputer simulations in stimulating environmental problem solving by community college students. Journal of Research in Science Teaching, 29, 453-470.

Flick, L. B. (1990): Interaction of intuitive physics with computer simulated physics. Journal of Research in Science Teaching, 27, 219-231.

Friedler, Y. - Nachmias, R. - Linn, M. G. (1990): Learning scientific reasoning skills in microcomputer-based laboratories. Journal of Research in Science Teaching, 27, 173-191.

Gall, J. E. - Hannafin, M. J. (1994): A framework for the study of hypertext. Instructional Science, 22, 207-232.

Glaser, R. - Raghavan, K. - Schauble, L. (1988): Voltaville, a discovery environment to explore the laws of DC circuits. In: Proceedings of the ITS-88 (61-66.): Montreal, Canada.

Glaser, R. - Schauble, L. - Raghavan, K. - Zeitz, C. (1992): Scientific reasoning across different domains. In: E. de Corte, M. Linn, H. Mandl, L. Verschaffel (Eds.), Computer-based learning environments and problem solving (345-373.): Berlin, Germany: Springer-Verlag. 
Grimes, P. W. - Willey, T. E. (1990): The effectiveness of microcomputer simulations in the principles of an economics course. Computers - Education, 14, 81-86.

Gruber, H. - Graf, M. - Mandl, H. - Renklés Stark, R. (1995, August): Fostering applicable knowledge by multiple perspectives and guided problem solving. Paper presented at the conference of the European Association for Reasearch on Learning and Instruction, Nijmegen, The Netherlands.

Hartel, H. (1994): COLOS: Conceptual Learning of Science. In: T. de Jong - L. Sarti (eds.), Design and production of multimedia and simulation based learning material (189-219): Dordrecht, Holland: Kluwer Academic Publishers.

de Jong, T. (1991): Learning and instruction with computer simulations. Education \&ृ Computing, 6, 217-229.

de Jong, T. - Hartel, H. - Swaak. J. - van Joolingen, W. (1996): Support for simulation-based learning; the effects of assignments in learning about transmission lines. In: A. Diaz de Ilarazza Sanchez - I. Fernandez de Castro (eds.), Computer aided learning and instruction in science and engineering, 9-27. Berlin, Germany: Springer-Verlag.

de Jong, T. - van Joolingen, W, Scott, D. - de Hoog, R. , Lapied, L. - Valent, R. (1994):

SMISLE: System for Multimedia Integrated Simulation Learning

Environments. In: T. de Jong - L. Sarti (eds.), Design and production of multimedia and simulation based learning material (133-167): Dordrecht, Holland: Kluwer Academic Publishers.

de Jong, T. - Martin, E. - Zamarro J-M. - Esquembre, F. - Swaak, J.és van Joolingen, W. R. (1995, April): Support for simulation-based learning: the effects of assignments and model progression in learning about collisions. Paper presented at the Annual Meeting of the American Educational Research Association, San Francisco, CA.

de Jong, T. - Njoo, M. (1992): Learning and Instruction with computer simulations: learning processes involved. In E. de Corte, M. Linn, H. Mandl - L. Verschaffel (eds.), Computer-based learning environments and problem solving, pp. 411-429. Berlin, Gemany, Springer-Verlag.

van Joolingen, W. R. (1995): QMaPS: Qualitative reasoning for intelligent simulation learning environments. Journal of Artificial Intelligence in Education, 6, $67-89$.

van Joolingen, W. R. - de Jong, T. (1991a): Characteristics of simulations for instructional settings. Education \& Computing, 6, 241-262.

van Joolingen, W. R. - de Jong, T. (1991b): Supporting hypothesis generation by learners exploring an interactive computer simulation. Instructional Science, 20, 389-404.

van Joolingen, W. R. - de Jong, T. (1993): Exploring a domain through a computer simulation: traversing variable and relation space with the help of a hypothesis scratchpad. In: D. Towne, T. de Jong - H. Spada (eds.), Simulation based experiential learning (pp. 191-206.): Berlin, Germany: SpringerVerlag.

van Joolingen, W. R. - de Jong, T. (1997): An extended dual search space model of learning with computer simulations. Instructional Science, 25, 307-346.

Kim, N. - Evens, M. - Michael, J. A. - Rovick, A. A. (1989): CIRCSIM TUTOR: An intelligent. tutoring system for circulatory physiology. In: H. Maurer (ed.), Computer 
Assisted Learning. Proceedings of the 2nd International Conference of ICCAL (254-267.):

Berlin, Germany: Springer-Verlag.

Klahr, D. - Dunbar, K. (1988): Dual space search during scientific reasoning. Cognitive Science,

$$
12,1-48 \text {. }
$$

Klahr, D. - Dunbar, K. - Fay, A.L. (1991): Designing experiments to test 'bad' hypotheses.

In: J. Shrager - P. Langley (eds.), Computational models of discovery and theory formation (355-401.): San Mateo, CA: Morgan Kaufman

Klahr, D. - Fay, A. L. - Dunbar, K. (1993): Heuristics for scientific experimentation: A developmental study. Cognitive Psychology, 25, 111-146.

Klayman, J. - Ha, Y-W. (1987): Confirmation, disconfirmation, and information in hypothesis testing. Psychological Review, 94, 211-228.

Kozma, R. B. - Russell, J. - Jones, T. - Marx, N. - Davis, J. (1996): The use of multiple, linked representations to facilitate science understanding. In: S. Vosniadou, E.

De Corte, R. Glaser - H. Mandl (eds.), International perspectives on the design of technology supported learning environments (41-61.): Hillsdale, NJ: Erlbaum.

Kuhn, D. - Schauble, L. - Garcia-Mila, M. (1992): Cross-domain development of scientific reasoning. Cognition and Instruction, 9, 285-327.

Kulkarni, D. - Simon, H. A. (1988): The processes of scientific discovery: The strategy of experimentation. Cognitive Science, 12, 139-175.

Lajoie, S. P. (1993): Cognitive tools for enhancing learning. In: S. P. Lajoie - S. J. Derry (eds.), Computers as cognitive tools (pp. 261-289.): Hillsdale, NJ: Erlbaum.

Laurillard, D. (1992): Learning through collaborative computer simulations. British Journal of Educational Technoloy, 23, 164-171.

Lavoie, D. R. - Good, R. (1988): The nature and use of predictions skills in a biological computer simulation. Journal of Research in Science Teaching, 25, 335-360.

Lesgold, A - Lajoie, S. - Bunzo, M. - Eggan, G. (1992): SHERLOCK: A coached practice environment for an electronics troubleshooting job. In: J. H. Larkin - R. W. Chabay (eds.), Computer-assisted instruction and intelligent tutoring systems: Shared goals and complementary approaches (201-239.): Hillsdale, NJ: Erlbaum.

Leutner, D. (1993): Guided discovery learning with computer-based simulation games: effects of adaptive and non-adaptive instructional support. Learning and Instruction, 3, 113-132.

Lewis, E. L. - Stern, J. L. - Linn, M. G. (1993): The effect of computer simulations on introductory thermodynamics understanding. Educational Technology, 33, 45-58.

Lindstrom, B. - Marton, F. - Ottosson, T.és Laurillard, D. (1993): Computer simulations as a tool for developing intuitive and conceptual understanding in mechanics. Computers in Human Behavior, 9, 263-281.

Linn, M. C. - Layman, J. - Nachmias, R. (1987): Cognitive consequences of microcomputerbased laboratories: Graphing skills development. Journal of Contemporary Educational Psychology, 12, 244-253.

Linn, M. C. - Songer, N. B. (1991): Teaching thermodynamics to middle school students: What are appropriate cognitive demands? Journal of Research in Science Teaching, 28, 885-918.

Mandl, H. - Gruber, H. - Renkl, A. (1994): Problems of knowledge utilization in the development of expertise. In: W. J. Nijhof - J. N. Streumer (eds.), Flexibility in training and vocational education (291-305.): Utrecht, Holland: Lemma BV 
Mayer, R. E. (1987): Educational psychology. A cognitive approach. Boston: Little, Brown and Company.

McDermott, L. C. (1990): Research and computer based instruction: Opportunity for interaction. American Journal of Physics, 58, 407-415.

Michael, J. A. - Haque, M. M. - Rovick, A. A.és Evens, M. (1989): The patho-physiology tutor: a first step towards a smart tutor. In H. Maurer (ed.), Computer Assisted Learning. Proceedings of the 2nd International Conference ICCAL (390-400.): Berlin, Germany, Springer-Verlag.

Mokros, J. R. - Tinker, R. F. (1987): The impact of microcomputer based labs on children's ability to interpret graphs. Journal of Research in Science Teaching, 24, 369-383.

Munro, A. - Fehling, M. R. - Towne, D. M. (1985): Instruction intrusiveness in dynamic simulation training. Journal of Computer-Based Instruction, 2, 50-53.

Njoo, M. - de Jong, T. (1993a): Exploratory learning with a computer simulation for control theory: Learning processes and instructional support. Journal of Research in Science Teaching, 30, 821-844.

Njoo, M. - de Jong, T. (1993b): Supporting exploratory learning by offering structured overviews of hypotheses. In: D. Towne - T. de Jong - H. Spada (eds.), Simulation-based experiential learning (207-225.): Berlin, Germany, SpringerVerlag.

Novak, J. D. - Wandersee, J. H. (1990): Perspectives on concept mapping [special issue]. Journal of Research in Science Teaching, 27, 921-1079.

Qin, Y. - Simon, H. A. (1990): Laboratory replication of scientific discovery processes. Cognitive Science, 14, 281-312.

Quinn, J. - Alessi, S. (1994): The effects of simulation complexity and hypothesis generation strategy on learning. Journal of Research on Computing in Education, 27, 75-91.

Reigeluth, C. M. - Schwartz, E. (1989): An instructional theory for the design of computerbased simulations. Journal of Computer-Based Instruction, 16, 1-10.

Reimann, P. (1991): Detecting functional relations in a computerized discovery environment. Learning and Instruction, 1, 45-65.

Reimann, P. - Beller, S. (1993): Computer-based support for analogical problem solving and learning. In: D. M. Towne, T. de Jong - H. Spada (Eds.), Simulation-based experiential learning (91-105.): Berlin, Germany: SpringerVerlag.

Rieber, L. P. (1990): Using computer animated graphics in science instruction with children. Journal of Educational Psychology, 82, 135-140.

Rieber, L. P. (1996): Animation as feedback in a computer-based simulation: representations matter. Educational Technology Research \& Development, 44, 5-23.

Rieber, L. P. - Boyce, M. - Assad, C. (1990): The effects of computer animation on adult learning and retrieval tasks. Journal of Computer-Based Instruction, 17, 46-52.

Rieber, L. P. - Parmley, M. W. (1995): To teach or not to teach? Comparing the use of computer-based simulations in deductive versus inductive approaches to learning with adults in science. Journal of Educational Computing Research, 14, 359-374.

Rieber, L. P. - Smith, M. - Al-Ghafry, S. - Strickland, B. - Chu, G.és Spahi, F. (1996): The role of meaning in interpreting graphical and textual feedback during a computer-based simulation. Computers \&̊ Education, 27, 45-58. 
Riley, D. (1990): Learning about systems by making models. Computers $\&$ Education, 15, 255-263.

Rivers, R. H. - Vockell, E. (1987): Computer simulations to stimulate scientific problem solving. Journal of Research in Science Teaching, 24, 403-415.

Schauble, L. - Glaser, R. - Duschl, R. A. - Schulze, S. - John, J. (1995): Students' understanding of the objectives and procedures of experimentation in the science classroom. The Journal of the Learning Sciences, 4, 131-166.

Schauble, L. - Glaser, R. - Raghavan, K. - Reiner, M. (1991): Causal models and experimentation strategies in scientific reasoning. The Journal of the Learning Sciences, 1, 201-239.

Schauble, L. - Klopfer, L. - Raghavan, K. (1991): Students' transitions from an engineering to a science model of experimentation. Journal of Research in Science Teaching, 28, 859-882.

Schauble, L. - Raghavan, K. - Glaser, R. (1993): The discovery and reflection notation: A graphical trace for supporting self regulation in computer-based laboratories. In: S. P. Lajoie - S. J. Derry (eds.), Computers as cognitive tools (319-341.): Hillsdale, NJ: Erlbaum.

Showalter, V M. (1970): Conducting science investigations using computer simulated experiments. The Science Teacher, 37, 46-50.

Shute, V. J. (1993): A comparison of learning environments: All that glitters... In: S. P. Lajoie - S. J. Derry (eds.), Computers as cognitive tools (47-75.): Hillsdale, NJ: Erlbaum.

Shute, V. J. - Glaser, R. (1990): large-scale evaluation of an intelligent discovery world: Smithtown. Interactive Learning Environments, 1, 51-77.

Simmons, R. E. - Lunetta, V. N. (1993): Problem-solving behaviors during a genetics computer simulation: beyond the expert/novice dichotomy. Journal of Research in Science Teaching, 30, 153-173.

Simon, H. A. - Lea, G. (1974): Problem solving and rule induction: a unified view. In: L. W.

Gregg (ed.), Knowledge and cognition (105-128.): Hillsdale, NJ: Erlbaum.

Smith, R. B. (1986): The Alternate Reality Kit: An animated environment for creating interactive simulations. Proceedings of IEEE Computer Society Workshop on Visual Programming (99-106.): Dallas, TX.

Suthers, D. - Weiner, A. - Connelly, J. - Paolucci, M. (1995): Belvedere: Engaging students in critical discussion of science and public policy issues. In: J. Greer (ed.), Proceedings of the AI-Ed 95, the $7^{\text {th }}$ World Conference on Artificial Intelligence in Education (266-273.): Charlottesville, VA: AACE.

Swaak, J. - de Jong, T. (1996): Measuring intuitive knowledge in science: the what-if test. Studies in Educational Evaluation, 22, 341-362.

Swaak, J. - van Joolingen, W. R. - de Jong, T. (1996): Support for simulation based learning; The effects of model progression and assignments on learning about oscillatory motion. Enschede, Holland: University of Twente, Centre for Applied Research on Education.

Tabak, I. - Smith, B. K. - Sandoval, W. A. - Reiser, B. J. (1996): Combining general and domain-specific strategic support for biological inquiry. In: C. Frasson, G. Gauthier - A. Lesgold (eds.), Intelligent Tutoring Systems (288-297.): Berlin, Germany, Springer-Verlag. 
Tait, K. (1994): DISCOURSE: The design and production of simulation-based learning environments. In: T. de Jong - L. Sarti (eds.), Design and production of multimedia and simulation-based learning material (111-133.): Dordrecht, The Netherlands: Kluwer Academic Publishers.

Teodoro, V. D. (1992): Direct manipulation of physical concepts in a computerized exploratory laboratory. In: E. de Corte - M. Linn - H. Mandl - L. Verschaffel (eds.), Computer-based learning environments and problem solving (NATO ASI series F: Computer and Systems Series) (445-465.): Berlin, Germany: Springer-Verlag.

Thomas, R. - Hooper, E. (1991): Simulations: an opportunity we are missing. Journal of Research on Computing in Education, 23, 497-513.

Thomas, R. - Neilson, I. (1995): Harnessing simulations in the service of education: the Interact simulation environment. Computers \& Education, 25, 21-29.

Thurman, R. A. (1993): Instructional simulation from a cognitive psychology viewpoint. Educational Technology Research \&̊ Development, 41, 75-89.

Thurman, R. A. - Mattoon, J. S. (1994): Virtual reality: Towards fundamental improvements in simulation-based training. Educational Technology, 34, 56-64.

Towne, D. M. (1995): Learning and instruction in simulation environments. Englewood Cliffs, NJ: Educational Technology Publications.

Veenman, M. V. J. - Elshout, J. J. (1995): Differential effects of instructional support on learning in simulation environments. Instructional Science, 22, 363-383.

Veenman, M. V. J. - Elshout, J. J. - Busato, V. V. (1994): Metacognitive mediation in learning with computer-based simulations. Computers in Human Behavior, 10, 93-106.

Wason, P. C. (1960): On the failure to eliminate hypotheses in a conceptual task. Quarterly Journal of Experimental Psychology, 12, 129-140.

Wason, P. G. (1966): Reasoning. In: B. M. Foss (ed.), New horizons in Psychology (135-151.): Harmondsworth, United Kingdom: Penguin.

White, B. Y. (1984): Designing computer games to help physics students understand Newton's laws of motion. Cognition and Instruction, 1, 69-108.

White, B. Y. (1993): ThinkerTools: causal models, conceptual change, and science education. Cognition and Instruction, 10, 1-100.

White, B. Y. - Frederiksen, J. R. (1989): Causal models as intelligent learning environments for science and engineering education. Applied Artificial Intelligence, 2-3, 83-106.

White, B. Y. - Frederiksen, J. R. (1990): Causal model progressions as a foundation for intelligent learning environments. Artificial Intelligence, 42, 99-157.

Whitelock, D. - Taylor, J. - O'Shea, T. - Scanlon, E. - Sellman, R. - Clark, P. - O’Malley, C. (1993): Challenging models of elastic collisions with a computer simulation. Computers \& Education, 20, 1-9.

Woodward, J. - Carnine, D. - Gersten, R. (1988): Teaching problem solving through computer simulations. American Educational Research Journal, 25, 72-86.

Zietsman, A. I. - Hewson, P. W. (1986): Effects of instruction using microcomputers simulations and conceptual change strategies on science learning. Journal of Research in Science Teaching, 23, 27-39. 


\section{A szerző megjegyzései}

Levelezési név és cím: Ton de Jong, Faculty of Educational Science and Technology, University of Twente, P.O. Box 217, 7500 AE Enschede, Hollandia. Email: jong@edte.utwente.nl. Az itt közölt munka egy része a SAFE/SIMUL.ATE, a SMISLE és a SERVIVE projektek keretében jött létre. Ezeket a projekteket részben az Európai Bizottság Telematics programjai támogatták. Nagyra értékeljük kollégáink hozzájárulását, ezektôl a projektektôl kezdve az itt közölt munkáig, különösen Jules Pieters és Janine Swaak (University of Twente), Melanie Njoo (jelenleg Origin Instruction Technology), Anja van der Hulst (jelenleg TNO, Physics and Electronics Laboratory) és Robert de Hoog (University of Amsterdam) segítségét köszönjük. Jules Pieters, Jeroen van Merrienboer (University of Twente), Patricia Alexander (University of Maryland) és Simon King (EDS-Ingevision) hasznos megjegyzéseket füztek a cikk vázlatához.

Copyright 1998, American Educational Research Association. Translated and reprinted with permission of the publisher. 